\title{
PERAN LEMBAGA KEUANGAN MIKRO (LKM) TERHADAP KINERJA EKONOMI KABUPATEN JOMBANG
}

\author{
Oleh: \\ Atut Frida Agustin \\ Mahasiswa Pascasarjana Universitas Brawijaya Malang \\ E-mail/No. Hp: atut_fa@gmail.com/-
}

\begin{abstract}
The objective of this study were: 1) To know the potential of Microfinance Institution (LKM) in Jombang Regency, 2) To know the role of Microfinance Institution (LKM) towards economic performance in Jombang Regency, 3)To know the needs of Microfinance Institution (LKM) Development in increasing LKM roles on the Jombang Regency economy. The results showed: First, the overall number of Microfinance Institutions (MFIs) in as many as 425 Jombang spread in 21 regencies. The regency which had LKM at most in Jombang regency for 154, the second was Ngusikan Regency. Second,The results of Econometric analysis were able to concluded that the amount of LKM, LKM capital, and the volume of bussiness impacted to the variable of economic growth in Jombang Regncy. Third, easy and soft loan had a degree of interest by $87 \%$ whereas direct aid only had a degree of interest of $13 \%$. Meanwhile, institutions which was more effective to provide capital loans on LKM development was institutional in rural areas, for example, through another microfinance.
\end{abstract}

Keywords: microfinance institution $(\mathrm{lkm})$, economic performance

\begin{abstract}
Abstrak
Tujuan yang akan dicapai dari hasil penelitian ini sebagai berikut: (1) Mengetahui potensi Lembaga Keuangan Mikro (LKM) di Kabupaten Jombang. (2) Mengetahui peran Lembaga Keuangan Mikro (LKM) terhadap kinerja ekonomi di Kabupaten Jombang. (3)Mengetahui kebutuhan pengembangan Lembaga Keuangan Mikro (LKM) dalam upaya peningkatan peran LKM terhadap ekonomi Kabupaten Jombang. Hasil penelitian menunjukkan: Pertama, secara keseluruhan jumlah Lembaga Keuangan Mikro (LKM) yang ada di Kabupaten Jombang sebanyak 425 yang tersebar di 21 kecamatan. Kecamatan yang mepunyai LKM paling banyak adalah Kecamatan Jombang yaitu sebesar 154, yang kedua adalah Kecamatan Ngusikan sebanyak 39 LKM. Kedua, hasil analisis ekonometri dapat disimpulkan bahwa jumlah LKM, modal LKM dan Volume Usaha berpengaruh positif terhadap variabel pertumbuhan ekonomi di kabupaten Jombang. Ketiga, bantuan pinjaman lunak dan mudah mempunyai nilai derajat kepentingan sebesar $87 \%$ sedangkan bantuan langsung hanya mempunyai nilai derajat kepentingan sebesar $13 \%$. Sementara kelembagaan yang lebih efektif untuk bisa menyediakan pinjaman modal terhadap pengembangan LKM adalah kelembagaan di wilayah desa, misalnya melalui microfinance yang lain.
\end{abstract}

Kata Kunci: lembaga keuangan mikro (lkm), kinerja ekonomi 


\section{PENDAHULUAN}

Pada Rencana Pembangunan Jangka Menengah Daerah Kabupaten Jombang tahun $2009 \quad-2013$ diamanatkan adanya upaya percepatan pembangunan perdesaan untuk meningkatkan tingkat perekonomian wilayah perdesaan yang selanjutnya diharapkan dapat mendorong peningkatan peran aktif masyarakat di dalam proses pembangunan di Kabupaten Jombang. Selain itu percepatan pembangunan perdesaan juga dimaksudkan untuk mempercepat perwujudan perekonomian daerah yang mandiri dan andal sebagai usaha bersama atas asas kekeluargaan, sehingga diperlukan upaya-upaya yang lebih nyata untuk menciptakan iklim yang mampu merangsang terselenggaranya aktivitas ekonomi kerakyatan yang sehat.

Pada hakekatnya inti dari konsepsi ekonomi kerakyatan adalah adanya kemitraan usaha yang kokoh diantara semua pelaku kehidupan ekonomi berdasarkan prinsip saling menguntungkan. Dengan terwujudnya kemitraan usaha yang kokoh tersebut diharapkan aktivitas perekonomian, khususnya di wilayah perdesaan dapat tumbuh dan berkembang semakin kuat, yang pada gilirannya dapat menjadi pondasi yang kokoh dalam rangka memantapkan struktur perekonomian daerah yang pada akhirnya akan bermuara pada meningkatnya kemandirian dan daya saing perekonomian daerah.

Untuk menjawab tantangan percepatan pembangunan perdesaan, khususnya yang terkait dengan aspek peningkatan perekonomian di wilayah perdesaan, optimalisasi potensi dan fungsi peran Lembaga Keuangan Mikro (LKM) yang telah banyak tumbuh dan mengakar dalam masyarakat perdesaan tentunya harus dikedepankan. Hal ini perlu dilakukan untuk mengeliminir permasalahan yang terkait dengan adanya keterbatasan modal serta kemampuan fiskal pemerintah daerah yang cenderung rendah.

Selain itu secara spesifik dalam konteks percepatan pembangunan ekonomi perdesaan potensi yang dapat diperankan LKM dalam memacu pertumbuhan ekonomi sangat besar. Setidaknya ada lima alasan untuk mendukung argumen tersebut. Pertama, LKM umumnya berada atau minimal dekat dengan kawasan pedesaan sehingga dapat dengan mudah diakses oleh para pelaku ekonomi di desa. Kedua, masyarakat 
desa lebih menyukai proses yang singkat dan tanpa banyak prosedur. Ketiga, karakteristik usaha masyarakat di perdesaan pada umumnya membutuhkan plafond kredit yang tidak terlalu besar sehingga sesuai dengan kemampuan finansial LKM. Keempat, dekatnya lokasi LKM dan pelaku usaha di perdesaan memungkinkan pengelola LKM memahami betul karakteristik usaha mikro dan kecil yang ada sehingga dapat mengucurkan kredit secara tepat waktu dan jumlah. Dan Kelima, adalah adanya keterkaitan sosial budaya serta hubungan yang bersifat personalemosional yang diharapkan dapat mengurangi sifat moral hazard dalam pengembalian kredit. Selain itu dalam skala yang lebih makro, keberadaan LKM di pedesaan dapat menjadi faktor kritikal dalam usaha penanggulangan kemiskinan yang efektif di wilayah perdesaan.

\section{Lembaga Keuangan Mikro} (LKM) atau Micro Finance Institution (MFI) merupakan lembaga yang melakukan kegiatan penyediaan jasa keuangan kepada pengusaha kecil dan mikro serta masyarakat berpenghasilan rendah yang tidak terlayani oleh Lembaga Keuangan formal dan yang telah berorientasi pasar untuk tujuan bisnis.

$$
\text { Menurut Siu }
$$

mendefinisikan bahwa lembaga keuangan mikro adalah lembaga yang menyediakan jasa keuangan kepada masyarakat miskin dan keluarga berpendapatan rendah (serta kegiatan usaha skala mikro mereka), memungkinkan mereka mengelola dengan lebih baik resikonya, mencapai pola konsumsi yang konsisten, serta mengembangkan basis ekonominya.

Bagaimanapun, target atau segmen micro finance senantiasa bersentuhan dengan masyarakat yang relatif miskin atau berpenghasilan rendah Program P4K yang ditangani di BRI mendefinisikan masyarakat miskin sebagai mereka petani, nelayan kecil (PNK) dan penduduk pedesaan lainnya yang hidup dibawah garis kemiskinan, dengan kriteria pendapatannya maksimum setara dengan $320 \mathrm{~kg}$ beras per kapita per tahun.

Banyaknya jenis lembaga keuangan mikro yang tumbuh dan berkembang di Indonesia menunjukkan bahwa lembaga keuangan mikro sangat dibutuhkan oleh masyarakat, terutama kelompok masyarakat berpenghasilan rendah, pengusaha kecil dan mikro yang selama ini belum terjangkau oleh 
jasa pelayanan keuangan perbankan khususnya bank umum.

Pada lembaga keuangan mikro ini dapat menumbuhkan minat masyarakat di pedesaan untuk berusaha atau menumbuhkan pengusahapengusaha kecil di pedesaan. Pada akhirnya peran LKM dapat membantu program pemerintah untuk meningkatkan produktivitas usaha masyarakat kecil di pedesaan, meningkatkan pendapatan penduduk desa, menciptakan lapangan kerja baru di pedesaan, sehingga dapat memperkecil keinginan masyarakat pedesaan melakukan urbanisasi, dan menunjang program pemerintah dalam mengupayakan pemerataan pendapatan penduduk desa dan upaya pengentasan kemiskinan.

\section{Perkembangan} lembaga keuangan mikro di Indonesia diilhami oleh keberhasilan Muhammad Yunus dalam mengembangkan LKM di Banglades yang terkenal dengan Grameen Bank (GB). Banyak orang melihat model GB sebagai suatu model pendekatan yang sukses dalam pengentasan kemiskinan dan peningkatan peran perempuan.

Melihat kesuksesan GB, banyak pihak yang mereplikasi metode GB terutama pada metode penyaluran pinjaman yang dilakukan kepada pengguna, tetapi tanpa mereplikasi sistem peningkatan kesejahteraan masyarakatnya yang berupa penyediaan layanan simpanan kecil dan penyediaan jaminan sosial. Padahal kesejahteraan masyarakat dalam arti sesungguhnya terletak pada pemilikan tabungan dan jaminan sosial di masa mendatang.

Keberhasilan pola GB di Indonesia mulai dilakukan pada tahun 1989 yang diprakarsai Puslitbang Sosek Pertanian Badan Litbang Pertanian yang pengelolaan selanjutnya dilakukan Yayasan Pengembangan Usaha Mandiri (YPKUM) berlokasi di Nanggung Jawa Barat. Berikutnya dilakukan di beberapa daerah lain seperti Tanggerang, di wilayah pasang surut Sumatera Selatan, Sulawesi Selatan, Jawa Timur dan tempat lain yang belum teridentifikasi.

Bagi Indonesia, keuangan mikro bukan hal baru. Pengelolaannya oleh Lembaga Keuangan Mikro sudah berkembang sejak lama dan telah menjadi topik pembicaraan para pakar dan praktisi ekonomi kerakyatan seperti antara lain Martowijoyo (2002), Sumodiningrat (2003), Budiantoro (2003), Syukur (2002), Ismawan (2005) dan lain-lain. Momentum 
pembahasan LKM senantiasa terkait dengan upaya penanggulangan kemiskinan, belum secara spesifik sebagai fasilitasi pembiayaan usahatani.

Menurut Wijono (2005), LKM di masyarakat sudah banyak dibentuk dan tersebar mulai dari perkotaan sampai perdesaan, atas prakarsa pemerintah, swasta maupun kalangan lembaga swadaya masyarakat dalam bentuknya yang formal, non formal, sampai informal dengan karakteristiknya masing-masing. Namun LKM tersebut memiliki fungsi yang sama sebagai intermediasi dalam aktivitas suatu perekonomian.

Banyak pihak meyakini LKM sebagai suatu alat pembangunan yang efektif untuk mengentaskan kemiskinan karena layanan keuangan memungkinkan orang kecil dan rumah tangga berpenghasilan rendah untuk memanfaatkan peluang ekonomi, membangun aset dan mengurangi kerentanan terhadap goncangan eksternal. LKM menjadi alat yang cukup penting untuk mewujudkan pembangunan dalam tiga hal sekaligus, yaitu: 1) menciptakan lapangan kerja, 2) meningkatkan pendapatan masyarakat, dan 3) mengentaskan kemiskinan (Anonim, 2007).
Menurut Martowijoyo (2002) dan Syukur (2006) gaung peranan kredit mikro untuk penciptaan lapangan kerja mandiri guna mengurangi kemiskinan ini mulai berkembang luas di dunia sejak ikrar Microcredit Summit di Washington DC, 1997.

Berkembangnya berbagai skema keuangan mikro dan semakin tingginya kebutuhan akan pengembangan pelayanan jasa keuangan bagi masyarakat miskin mendorong terbentuknya forum Gerakan Bersama Pengembangan Keuangan Mikro (Gema PKM) untuk mengembangkan keuangan mikro sebagai industri agar menjangkau masyarakat miskin secara lebih luas. Gema PKM disahkan presiden pada tahun 2000, beranggotakan tujuh pemangku kepentingan yaitu pihak pemerintah, lembaga keuangan, LSM, pihak swasta, akademisi atau peneliti, organisasi massa, serta lembaga pendanaan (Anonim, 2007).

Walaupun di lingkungan masyarakat telah banyak tumbuh dan berkembang lembaga keuangan yang terlibat di dalam pembiayaan usaha mikro dengan beragam bentuk seperti bank umum atau Bank Perkreditan Rakyat (BPR), modal ventura, program Pengembangan Usaha Kecil dan 
Koperasi (PUKK), pegadaian dan sebagainya (Retnadi, 2003), namun kesenjangan antara permintaan dan penawaran layanan keuangan mikro masih tetap ada. Di sektor pertanian, maraknya LKM di masyarakat itu belum serta merta diikuti oleh pemenuhan kebutuhan permodalan bagi petani. Faktanya, kebutuhan permodalan petani untuk pembiayaan usahatani selalu menjadi persoalan.

Lembaga jasa finansial berupa Lembaga Keuangan Mikro (LKM) pada dasarnya sangat diperlukan untuk mendukung kegiatan pembangunan ekonomi pedesaan utamanya sebagai lembaga fasilitasi jasa pembiayaan usahatani. Hal itu didasarkan fakta hampir sebagian besar petani menghadapi permasalahan adopsi teknologi karena lemah dalam permodalan. Di sisi lain lembaga perbankan sering tidak bisa diakses oleh petani karena berbagai faktor.

Berdasarkan uraian diatas, maka tujuan yang akan dicapai dari hasil penelitian ini adalah untuk mengetahui potensi Lembaga Keuangan Mikro (LKM) di Kabupaten Jombang, untuk mengetahui peran Lembaga Keuangan Mikro (LKM) terhadap kinerja ekonomi di Kabupaten Jombang, dan untuk mengetahui kebutuhan pengembangan Lembaga Keuangan Mikro (LKM) dalam upaya peningkatan peran LKM terhadap ekonomi Kabupaten Jombang.

\section{METODE PENELITIAN}

Secara umum penelitian ini dilakukan di wilayah perdesaan maupun perkotaan, khususnya yang terdapat Lembaga Keuangan Mikro serta wilayah cakupan pelayanannya. Ruang lingkup lokasi studi di Kabupaten Jombang yang meliputi seluruh wilayah sebanyak 21 kecamatan. Secara umum unit analisis meliputi Kabupaten Jombang dengan unit terkecil tingkat kecamatan.

Kegiatan penelitian ini, meliputi sebagai berikut: 1) Melakukan survei awal; 2) Melakukan pengumpulan data ekonomi daerah Kabupaten Jombang; 3) Mengidentifikasi seluruh sumber daya yang terkait dengan LKM di Kabupaten Jombang; 4) Melakukan analisis jenis, kapasitas dan perkembangan perekonomian wilayah di Kabupaten Jombang; 5) Melakukan analisis terhadap kebijakan pembangunan sektoral maupun spasial di Kabupaten Jombang; 6) Melakukan analisis LKM terkait kegiatan ekonomi di Kabupaten Jombang; 7) Menyusun informasi tentang LKM di Kabupaten 
Jombang; dan 8) Menyusun arahan kebijakan pengembangan LKM di Kabupaten Jombang.

\section{PEMBAHASAN}

Lembaga keuangan mikro formal yang ada di Kabupaten Jombang hampir seluruhnya berbentuk badan koperasi. Sampai saat ini kurang lebih ada 17 (tujuh belas) jenis koperasi yang masih aktif di Kabupaten Jombang, yaitu: Koperasi Unit Desa (KUD); Kopontren; Kopinkra; Koptan; KPTR; KPRI; Koperasi Angkatan Darat; Koperasi Kepolisian; Koperasi Serba Usaha; Koperasi Pasar; Koperasi Simpan Pinjam; Koperasi Angkutan Darat; Koperasi Wanita; Koperasi Wredatama; Koperasi Mahasiswa, Koperasi Pemuda; Koperasi Lingmas; dan Koperasi lain-lain.

Secara keseluruhan jumlah Lembaga Keuangan Mikro (LKM) yang ada di Kabupaten Jombang sebanyak 424 yang tersebar di 21 Kecamatan. Kecamatan yang mepunyai LKM paling banyak adalah Kecamatan Jombang yaitu sebesar 154, yang kedua adalah Kecamatan Ngusikan sebanyak 39 LKM. Sedangkan Kecamatan yang mempunyai LKM paling sedikit adalah Kecamatan Jogoroto dan Bandar Kedung Mulyo, kedua Kecamatan tersebut masing-masing mempunyai 6 (enam) Lembaga Keuangan Mikro (LKM).

Secara terperinci dapat diuraikan yaitu: Kecamatan Jombang memiliki 154 LKM, Kecamatan Ngusikan memiliki 39 LKM, Kecamatan Diwek memiliki 25 LKM, Kecamatan Mojoagung memiliki 24 LKM, Kecamatan Peterongan memiliki 24 LKM, Kecamatan Gudo memiliki 14 LKM, Kecamatan Ngoro memiliki 13 LKM, Kecamatan Bareng memiliki 13 LKM, Kecamatan Mojowarno memiliki 13 LKM, Kecamatan Sumobito memiliki 12 LKM, Kecamatan Perak memiliki 11 LKM, Kecamatan Tembelang memiliki 10 LKM, Kecamatan Megaluh memiliki 10 LKM.

Kecamatan Ploso 9 LKM, Kecamatan Kudu memiliki 9 LKM, Kecamatan Wonosalam memiliki 9 LKM, Kecamatan Plandaan memiliki 8 LKM, Kecamatan Kesamben memiliki 8 LKM, Kecamatan Kabuh memiliki 7 LKM, Kecamatan Jogoroto memiliki 6 LKM dan Kecamatan Bandar Kedung Mulyo memiliki 6 LKM.

Adapun jumlah karyawan yang bekerja pada LKM di kabupaten Jombang berjumlah 2.524 orang dengan jumlah anggota sebanyak 
122.016 orang. Adapun total Aset LKM di kabupaten Jombang yaitu sebesar Rp. 243.666.251.000,-.

Jumlah karyawan terbesar terdapat pada Kecamatan Jombang, yaitu sebanyak 1.041 orang, hal ini berarti LKM di Kecamatan Jombang mampu menyerap tenaga kerja dibandingkan dengan Kecamatan lainnya. Begitu pula dengan jumlah anggota dan aset terbesar berada pada Kecamatan Jombang yaitu 28.366 anggota dan asetnya Rp. 123.256.939.000,-. Jumlah karyawan paling sedikit berada pada Kecamatan Jogoroto, yaitu hanya 22 orang. Sedangkan jumlah anggota paling sedikit pada Kecamatan Ploso yaitu hanya 1.250 orang. Untuk aset yang paling sedikit berada pada Kecamatan Megaluh yaitu sebesar Rp. 348.168.000,-.

Jumlah karyawan LKM di Kecamatan Jombang jauh lebih banyak dibandingkan Kecamatan lainnya yaitu sebanyak 1.041 orang dengan jumlah anggota 28.366 orang. Kecamatan yang kedua terbanyak yaitu Kecamatan Ngusikan sebanyak 320 orang dengan jumlah anggota 4.208 orang.

Sedangkan aset LKM yang paling besar berada pada Kecamatan Jombang yaitu sebesar Rp.
123.256.939.000,-. Kemudian posisi kedua yaitu Kecamatan Mojoagung sebesar Rp. 20.802.858.000,-.

Sedangkan dari aspek modal LKM di Kabupaten Jombang terdiri dari modal sendiri dan modal luar. Untuk modal sendiri total di Kabupaten Jombang yaitu sebesar Rp. 90.083.529.000,-, modal luar sebesar Rp. 154.564.632.000,- yang bila ditotal yaitu sebesar Rp. 244.648.161.000,-. hal ini berarti komposisi modal luar di Kabupaten Jombang lebih besar dibandigkan modal sendiri.

Modal sendiri dan modal luar terbesar berada pada Kecamatan Jombang yaitu untuk modal sendiri sebesar Rp. 52.025.093.000,- dan sebesar Rp. 71.270.017.000,- untuk modal luar. Modal sendiri paling sedikit berada pada Kecamatan Jogoroto yaitu sebesar Rp. 119.795.000,--. Sedangkan untuk modal luar dan total modal paling sedikit berada pada Kecamatan Megaluh, yaitu modal sendiri sebesar Rp. 204.288.000,- dan Total Modal sebesar Rp. 350.238.000,-.

Secara keseluruhan Volume Usaha LKM di kabupaten Jombang yaitu sebesar Rp. 232.954.697.000,-, dengan Sisa Hasil Usaha (SHU) yaitu sebesar Rp. 9.407.807.000,-. Volume 
Usaha dan SHU terbesar berada pada Kecamatan Jombang yaitu untuk Volume Usaha sebesar Rp. 119.902.532.000,- dan sebesar Rp. 5.024.483.000,- untuk SHU.

Volume usaha paling sedikit dimiliki Kecamatan Megaluh yaitu sebesar Rp. 110.977.000,-. Sedangkan SHU yang paling sedikit dimiliki Kecamatan Perak yaitu sebesar Rp. 3.582.000,--

Agar mengetahui besarnya pengaruh Jumlah LKM Formal $\left(\mathrm{X}_{1}\right)$, Modal LKM Formal $\left(\mathrm{X}_{2}\right)$ dan Volume Usaha $\left(\mathrm{X}_{3}\right)$ terhadap Produk Domestik Regional Bruto PDRB (Y) di Kabupaten Jombang dilakukan dengan alat regresi linier berganda, adapun model hasil analisis dapat diinterpretasinya sebagi berikut :

$\log Y=\beta_{0}+\beta_{1} \log X_{1}+\beta_{2} \log X_{2}+\beta_{3} \log X_{3}$ $\log Y=11,729+0,559 \log X_{1}+0,053 \log X_{2}+0,027 \log X_{3}$

Nilai $\beta_{0}$ sebesar 11,729 berarti nilai PDRB ( $\log Y)$ sebesar 11,73\% pada saat Jumlah LKM Formal $\left(\log X_{1}\right)$, Modal LKM Formal $\left(\log X_{2}\right)$, dan Volume Usaha $\left(\log X_{3}\right)$ sama dengan atau dianggap nol (konstan).

Nilai $\quad \beta_{1}$ yang merupakan koefisien regresi variabel Jumlah LKM Formal $\left(\log \mathrm{X}_{1}\right)$ sebesar 0,559 berarti ada pengaruh positif antara Jumlah LKM Formal terhadap PDRB sebesar 0,559\%. Apabila Jumlah LKM Formal $\left(\log \mathrm{X}_{1}\right)$ naik sebesar 1\% maka PDRB (LogY) juga akan mengalami kenaikan sebesar 0,559\%. Sebaliknya apabila Jumlah LKM Formal $\left(\log \mathrm{X}_{1}\right)$ turun sebesar 1\% maka PDRB (LogY) juga akan turun sebesar $0,559 \%$.

Nilai $\quad \beta_{2}$ yang merupakan koefisien regresi variabel Modal LKM Formal $\left(\log \mathrm{X}_{2}\right)$ sebesar 0,053 berarti ada pengaruh positif Modal LKM Formal terhadap PDRB sebesar 0.053\%. Apabila Modal LKM Formal $\left(\log \mathrm{X}_{2}\right)$ naik sebesar 1\% maka PDRB (Log Y) akan mengalami kenaikan sebesar 0,053\%. Sebaliknya apabila Modal LKM Formal $\left(\log \mathrm{X}_{2}\right)$ turun sebesar 1\% maka PDRB (Log Y) akan turun sebesar $0.053 \%$.

Nilai $\beta_{3}$ yang merupakan koefisien regresi variabel Volume Usaha $\left(\log \mathrm{X}_{3}\right)$ sebesar 0,027 berarti ada pengaruh positif Volume Usaha terhadap PDRB sebesar $0,027 \%$. Apabila Volume Usaha $\left(\log \mathrm{X}_{3}\right)$ naik sebesar 1\% maka PDRB (Log Y) juga akan mengalami kenaikan sebesar $0.027 \%$. Sebaliknya apabila Volume Usaha $\left(\log \mathrm{X}_{2}\right)$ turun sebesar $1 \%$ maka PDRB (Log Y) juga akan turun sebesar $0,027 \%$. 
Dari hasil regresi berganda diatas dapat disimpulkan bahwa Jumlah LKM Formal, Modal LKM Formal dan Volume Usaha berpengaruh positif terhadap variabel terkait (PDRB).

Adapun koefisien determinasi digunakan untuk melihat kontribusi variabel bebas terhadap variabel terikat. Koefisien determinasi $\left(\mathrm{R}^{2}\right)$ maupun koefisien determinasi yang disesuaikan menunjukkan variabel penjelas dalam menjelaskan variasi variabel terikat. Jika nilai $\mathrm{R}^{2}$ semakin mendekati 1 maka dapat dinyatakan model semakin baik dengan asumsi tidak terjadi regresi lancung. Dari analisa perhitungan diperoleh nilai $\mathrm{R}^{2}$ (R-squared) seperti dalam tabel berikut.

Berdasarkan hasil analisis didapatkan koefisien determinasi $\mathrm{R}^{2}$ sebesar 0,501 Artinya bahwa 50,1\% variabel PDRB akan dijelaskan oleh variabel bebasnya, yaitu Jumlah LKM Formal, Modal LKM Formal, dan Volume Usaha. Sedangkan sisanya sebesar 49,9\% variabel PDRB akan dijelaskan oleh variabel-variabel yang lain yang tidak dibahas dalam kajian ini.

Sedangkan besarnya pengaruh Jumlah LKM Non Formal $\left(\mathrm{X}_{1}\right)$ dan Modal LKM Non Formal $\left(\mathrm{X}_{2}\right)$ terhadap Pertumbuhan Ekonomi (Y) di
Kabupaten Jombang juga dilakukan dengan alat regresi linier berganda, pemilihan variabel bebas tidak mengikutsertakan Volume Usaha sebagaimana pada LKM Formal dikarenakan dalam LKM Non Formal nilai Volume Usaha relative sama, adapun model hasil analisis dapat diinterpretasinya sebagi berikut :

$\log Y=\beta_{0}+\beta_{1} \log X_{1}+\beta_{2} \log X_{2}$ $\log Y=0,816+0,003 \log X_{1}+0,0442 \log X_{2}$ Nilai $\beta_{0}$ sebesar 0,816 berarti nilai pertumbuhan ekonomi ( $\log \mathrm{Y})$ sebesar 0,816\% pada saat Jumlah LKM Non Formal $\left(\log X_{1}\right)$, Modal LKM Non Formal $\left(\log \mathrm{X}_{2}\right)$ sama dengan atau dianggap nol (konstan).

Nilai $\beta_{1}$ yang merupakan koefisien regresi variabel Jumlah LKM Non Formal $\left(\log \mathrm{X}_{1}\right)$ sebesar 0,003 berarti ada pengaruh positif antara Jumlah LKM Non Formal terhadap Pertumbuhan Ekonomi sebesar 0,003\%. Apabila Jumlah LKM Non Formal $\left(\log X_{1}\right)$ naik sebesar 1\% maka Pertumbuhan Ekonomi ( $\log Y)$ juga akan mengalami kenaikan sebesar 0,003\%. Sebaliknya apabila Jumlah LKM Non Formal $\left(\log X_{1}\right)$ turun sebesar $1 \%$ maka Pertumbuhan Ekonomi (LogY) juga akan turun sebesar $0,003 \%$. 
Nilai $\beta_{2}$ yang merupakan koefisien regresi variabel Modal LKM Non Formal $\left(\log \mathrm{X}_{2}\right)$ sebesar 0,0442 berarti ada pengaruh positif Modal LKM Non Formal terhadap Pertumbuhan Ekonomi sebesar 0,0442\%. Apabila Modal LKM Non Formal $\left(\log \mathrm{X}_{2}\right)$ naik sebesar $1 \%$ maka Pertumbuhan Ekonomi (Log Y) akan mengalami kenaikan sebesar 0,0442\%. Sebaliknya apabila Modal LKM Non Formal $\left(\log \mathrm{X}_{2}\right)$ turun sebesar $1 \%$ maka Pertumbuhan Ekonomi (Log Y) akan turun sebesar $0.0442 \%$.

Dari hasil regresi berganda diatas dapat disimpulkan bahwa Jumlah LKM Non Formal dan Modal LKM Non Formal berpengaruh positif terhadap variabel terkait (Pertumbuhan Ekonomi).

Adapun koefisien determinasi digunakan untuk melihat kontribusi variabel bebas terhadap variabel terikat. Koefisien determinasi $\left(\mathrm{R}^{2}\right)$ maupun koefisien determinasi yang disesuaikan menunjukkan variabel penjelas dalam menjelaskan variasi variabel terikat. Jika nilai $\mathrm{R}^{2}$ semakin mendekati 1 maka dapat dinyatakan model semakin baik dengan asumsi tidak terjadi regresi lancung.

Berdasarkan hasil analisis didapatkan koefisien determinasi $\mathrm{R}^{2}$ sebesar 0,174 Artinya bahwa 17,4\% variabel Pertumbuhan Ekonomi akan dijelaskan oleh variabel bebasnya, yaitu Jumlah LKM Non Formal dan Modal LKM Non Formal. Sedangkan sisanya sebesar $82,6 \%$ variabel Pertumbuhan Ekonomi akan dijelaskan oleh variabel-variabel yang lain yang tidak dibahas dalam kajian ini.

Dalam upaya mengetahui pengetahuan pengembangan LKM di Kabupaten Jombang dilakukan dengan Analisis Hierarki Proses (AHP). AHP merupakan suatu metoda yang menstruktur masalah, dalam bentuk hierarki dan memasukkan pertimbangan-pertimbangan untuk menghasilkan skala prioritas relatif. Analisis Hierarki Proses juga dapat memecahkan persoalan dengan prinsip menyusun hierarki, prinsip menetapkan prioritas, dan prinsip konsistensi logis dalam pengambilan suatu keputusan.

Struktur yang dibangun untuk mementukan model perencanaan pengembangan Lembaga Keuangan Mikro (LKM) di Kabupaten Jombang dapat dilihat pada gambar 1.

Hasil perhitungan faktor penentu yang digunakan untuk kebijakan strategis dalam upaya meningkatkan peran LKM dalam pertumbuhan ekonomi masyarakat berdasarkan 
Analisis Hiraki Proses (AHP), atau dinginkan adalah kesejahteraan. menunjukkan bahwa dari aspek akses Dengan kata lain kesejahteraan lebih pasar kebutuhan yang mutlak berpengaruh secara signifikan dalam diperlukan adalah infrastruktur gedung kualitas pelayanan dibanding pelatihan. terutama di tingkat desa.

Berikut ini gambaran hirarki strategi

Dari aspek operasional, faktor kebijakan dari aspek operasional. yang sangat dominan mempengaruhi

\section{Gambar 1. Struktur Hirarki Kebijakan Dengan Model AHP}

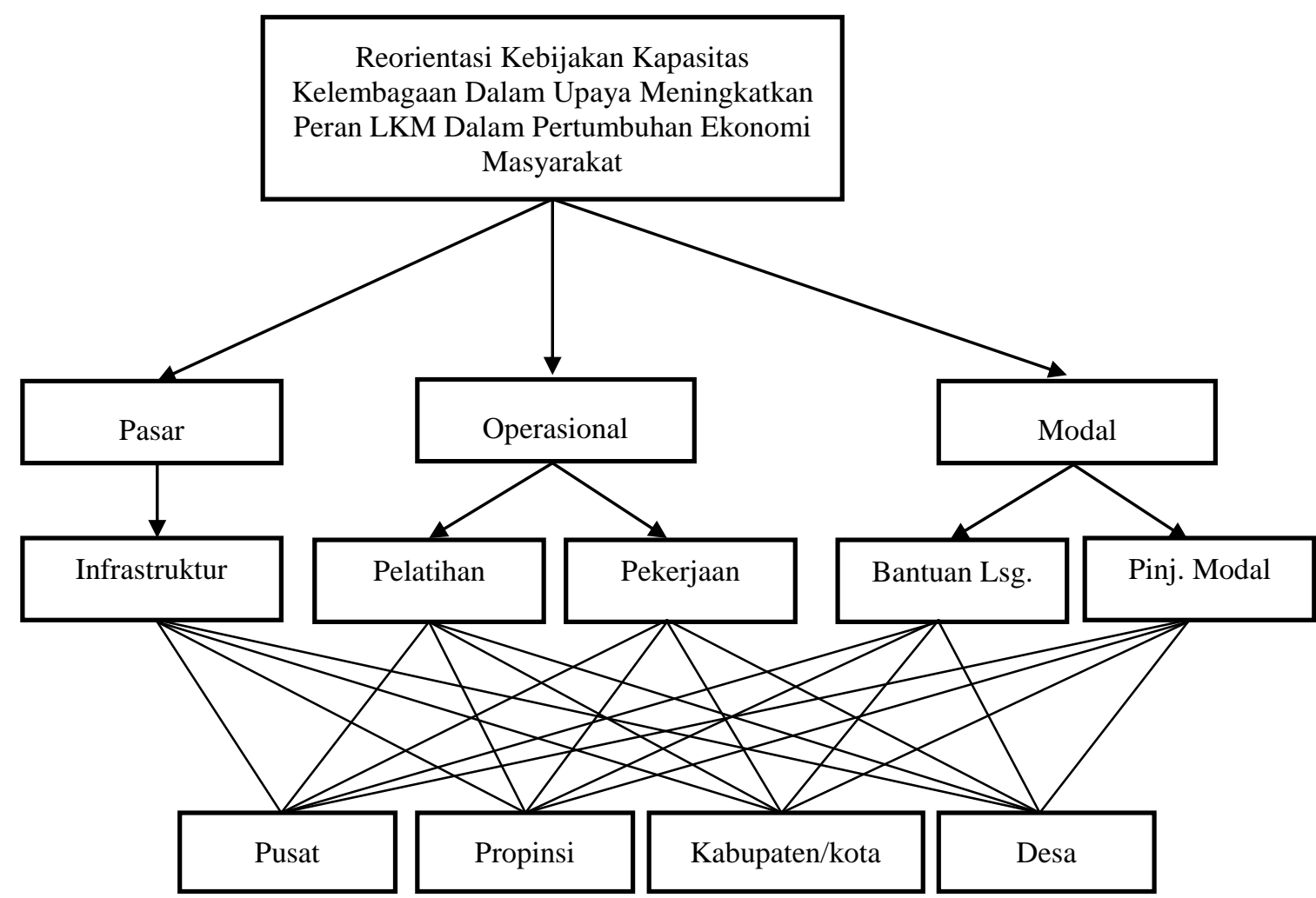

Sumber : Data diolah 
Gambar 2. Struktur Hirarki Kebijakan Dari Aspek Akses Produksi

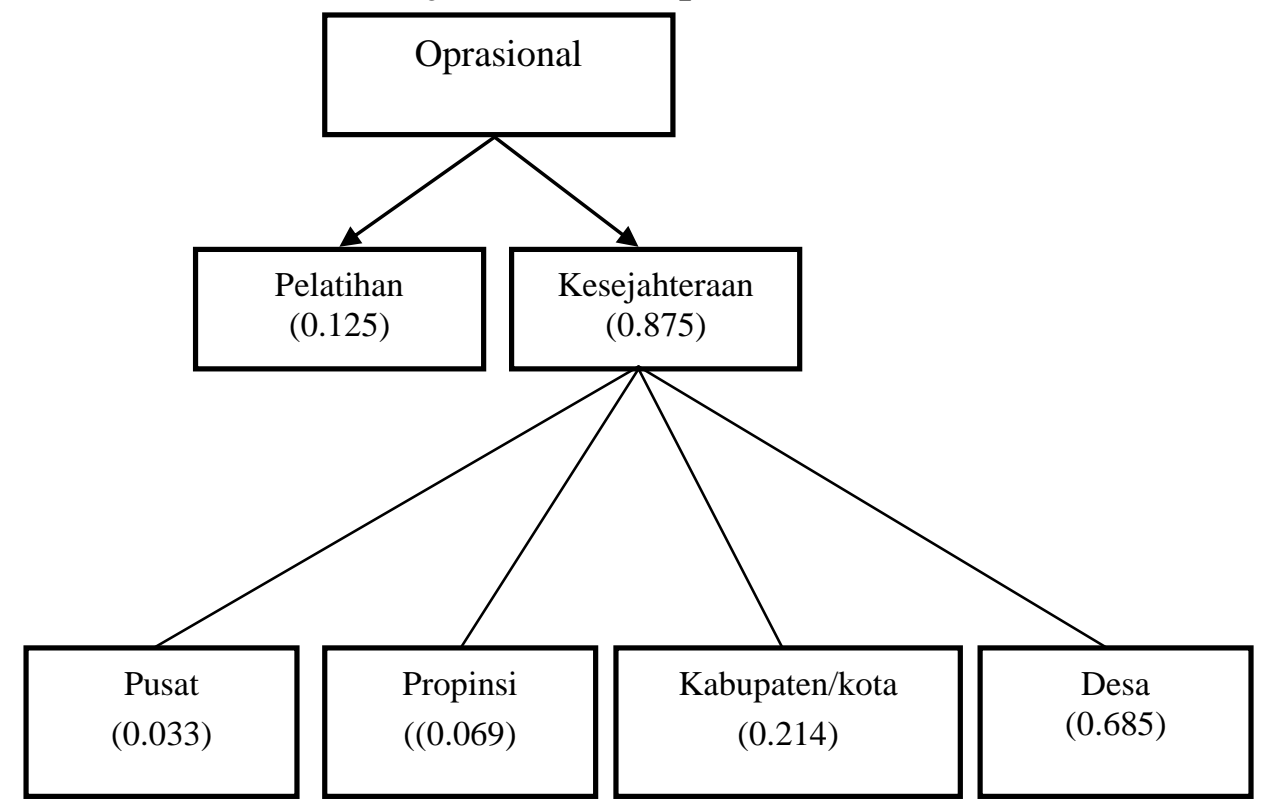

Sumber : Data diolah

\section{Gambar 3. Struktur Hirarki Kebijakan Dari Aspek Akses Produksi Untuk Variabel Pelatihan}

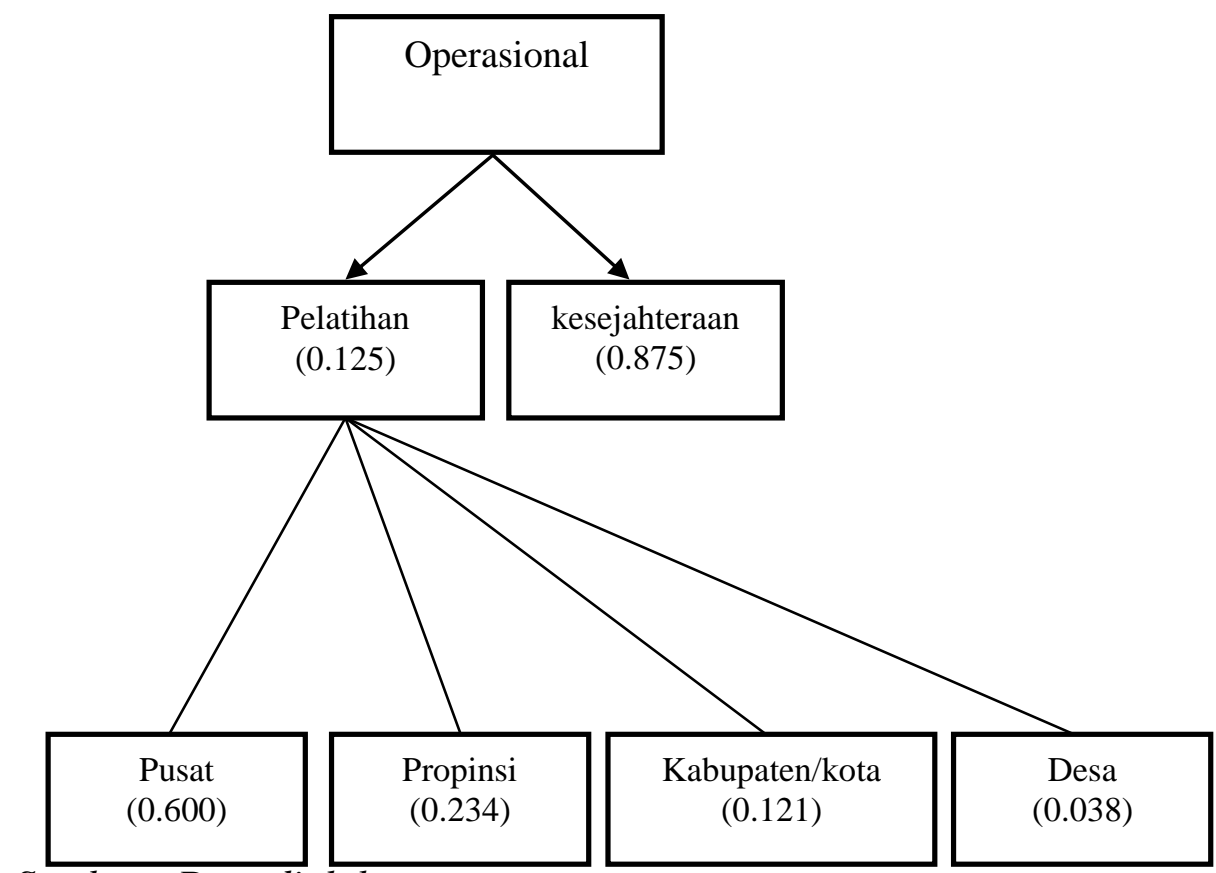

Sumber : Data diolah

Dari gambar di atas terlihat nilai derajat kepentingan sebesar bahwa faktor kesejahteraan mempunyai $12.5 \%$. Sementara kelembagaan yang nilai derajat kepentingan sebesar $87.5 \%$ lebih efektif untuk bisa meningkatkan sedangkan pelatihan hanya mempunyai 
kesejahteraan pengelola LKM adalah kelembagaan di wilayah desa.

Berdasarkan hasil analisis menunjukkan bahwa derajat kepentingan kelembagaan di tingkat desa mempunyai nilai $68.5 \%$, kemudian disusul oleh kelembagaan di tingkat kabupaten/kota dan propinsi. Sedangkan kelembagaan di tingkat pusat mempunyai nilai derajat kepentingan paling rendah yaitu hanya sebesar $\quad 0.33 \%$. Kondisi ini menggambarkan bahwa kelembagaan di tingkat lokal yang paling kecil lebih efektif dalam meningkatkan kesejahteraan pengelola LKM dibanding kelembagaan di tingkat pusat.

Sedangkan apabila pelatihan memang dibutuhkan untuk meningkatkan kemampuan dan keterampilan pengelola LKM, maka dari hasil analisis menunjukkan bahwa kelembagaan pemerintah pusat lebih efektif dalam membuat program dan bentuk pelatihannya. Berikut ini gambaran derajat kepentingan kelembagaan di tingkat desa sampai pusat, dalam memberikan pelatihan.

Berdasarkan hasil analisis menunjukkan bahwa derajat kepentingan kelembagaan di tingkat pusat mempunyai nilai $60.0 \%$, kemudian disusul oleh kelembagaan di tingkat propinsi dan kabupaten/kota. Sedangkan kelembagaan di tingkat desa mempunyai nilai derajat kepentingan paling rendah yaitu hanya sebesar $0.38 \%$ Kondisi ini menggambarkan bahwa kelembagaan di tingkat pusat dianggap lebih baik dari pada kelembagaan ditingkat lokal dalam hal memberikan pelatihan terhadap petugas LKM. Hal tersebut disebabkan karena alasan bahwa biasanya program-program pelatihan ditingkat pusat lebih baik dan menggunakan teknologi yang tepat guna untuk kebutuhan pengelola LKM.

Dari aspek modal, faktor yang sangat dominan mempengaruhi atau dinginkan adalah berupa bantuan atau pinjaman modal yang bersifat lunak. Dengan kata lain pinjaman modal atau bantuan modal lebih berpengaruh secara signifikan dalam meningkatkan peran LKM terhadap peningkatan ekonomi masyarakat dibanding bantuan langsung. Berikut ini gambaran hirarki strategi kebijakan dari aspek akses modal.

Dari gambar 4 terlihat bahwa bantuan pinjaman lunak dan mudah mempunyai nilai derajat kepentingan sebesar $87 \%$ sedangkan bantuan langsung hanya mempunyai nilai 
derajat kepentingan sebesar 13\% pengembangan LKM adalah Sementara kelembagaan yang lebih kelembagaan di wilayah desa, misalnya efektif untuk bisa menyediakan melalui micro finance yang lain. pinjaman modal terhadap

\section{Gambar 4. Struktur Hirarki Kebijakan Dari Aspek Akses Modal}

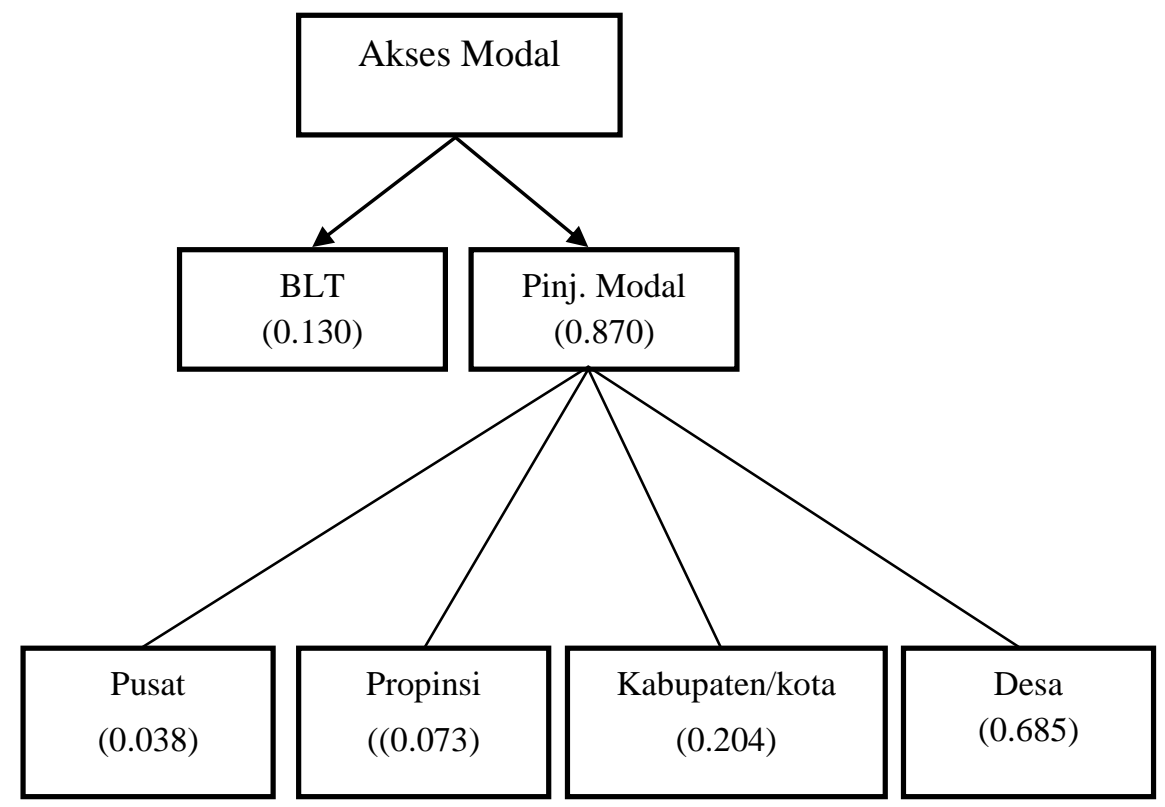

Sumber : Data diolah

Berdasarkan hasil analisis

menunjukkan bahwa derajat

kepentingan kelembagaan di tingkat desa mempunyai nilai $68.5 \%$, kemudian disusul oleh kelembagaan di tingkat kabupaten/kota dan propinsi. Sedangkan kelembagaan di tingkat pusat mempunyai nilai derajat kepentingan paling rendah yaitu hanya sebesar $0.38 \%$ Kondisi ini menggambarkan bahwa kelembagaan keuangan di tigkat lokal (terutama desa) yang paling kecil lebih efektif dalam menyediakan akses modal kerja dibanding kelembagaan di tingkat pusat.
Adapun hasil analisis SWOT terhadap Lembaga Keuangan Mikro (LKM) di Kabupaten Jombang menjelaskan kondisi LKM secara umum di Kabupaten Jombang, dimana faktor internal LKM dapat diidentifikasikan bahwa kekuatan LKM lebih banyak daripada kelemahannya.

Pada aspek sumber daya manusia atau tenaga kerja terdapat kemudahan dalam tenaga kerja, yaitu tenaga kerja didapatkan dari penduduk setempat/lokal. Dengan begitu keberadaan dari LKM turut mengurangi jumlah pengangguran yang ada di Kabupaten Jombang. Kekuatan 
lain pada faktor sumber daya manusia yang ada pada sektor LKM adalah cukup tingginya rata-rata tingkat pendidikan responden, yaitu $56 \%$ ada SMA, 27\% lulusan perguruan tinggi, $11 \%$ lulusan SLTP dan 6\% lulusan SD.

Analisis kekuatan aspek keuangan, secara umum dapat dijelaskan bahwa untuk modal kerja tidak mengalami banyak kendala, dalam artian untuk LKM jenis koperasi komposisi permodalan banyak berasal dari simpanan wajib anggota sendiri. Koperasi juga menggunakan hutang / pinjaman untuk membiayai usahanya, sehingga kesempatan untuk mengembangkan usaha Iebih luas dan lebih terbuka.

Analisis kelemahan dari aspek keuangan yaltu dengan adanya pinjaman / hutang untuk biayai usaha mereka menyebabkan adanya hutang yang harus diperhitungkan pengembaliannya sehingga tidak membebani usaha mereka.

Analisis kekuatan dari aspek operasional dan pemasaran LKM adalah sangat besar di mana produk di dapat dari daerah sekitar/lokal maupun maupun dari luar daerah dengan tingkat kualitas produk yang baik. Banyaknya pemasok sektor pedagangan merupakan salah satu kekuatan lain.
Lokasi yang strategis yaitu mendekati masyarakat merupakan kekuatan yang dimiliki LKM yang ada di Kabupaten Jombang.

KeIemahan dari aspek operasional dan pemasaran adalah meskipun memiliki banyak pemasok, ternyata masih sering menerima keluhan dari pelanggan seputar produk dan pelayanan dibandingkan pada institusi lain.

Pada aspek perijinan mereka rasakan bahwa proses mengurus perijinan LKM tidak terlalu susah atau wajar. Sehingga pada aspek ini cukup dipertahankan atau jika bisa lebih ditingkatkan untuk di masa mendatang.

Berdasarkan External Factor Evaluation dapat dihasilkan peluang yang dimiliki LKM Kabupaten Jombang yakni masih terbuka luasnya pasar dalam negeri dan luar negeri untuk memasarkan produk-produk LKM. Adanya dukungan sepenuhnya dari pemerintah dan instansi swasta terhadap pegembangan LKM. Banyak tersedianya lembaga keuangan yang akan membantu permodalan LKM juga menjadi salah satu peluang bagi pengembangan LKM. Peluang lainnya adalah muncul teknologi baru di bidang informasi dan komunikasi yang sangat 
menunjang kegiatan LKM, termasuk mengakses pasar dengan cepat.

Ancaman yang dihadapi oleh LKM adalah semakin tajamnya persaingan produk-produk dari instansi lain atau import yang sebagai akibat dibukanya lalu lintas perdagangan bebas. Masih lemahnya pengaturan dan penegakan hukum menjadi salah ancaman bagi LKM. Rendahnya tingkat kepercayaan masyarakat terhadap kualitas produk LKM turut menjadi ancaman pengembangan LKM.

\section{PENUTUP}

Secara konseptual pengembangan LKM Kabupaten Jombang perlu memperlihatkan indikator yang mendasarinya, indikator tersebut, meliputi: a) Aspek sumber daya manusia; b) Aspek pemasaran; c) Aspek permodalan dan investasi; d) Aspek perijinan.

Sebagaimana ditunjukkan pada pembahasan sebelumnya bahwa sumber daya manusia merupakan aspek yang menjadi indikator pengembangan LKM, aspek SDM meliputi: tingkat pendidikan pegawai dan pengetahuan pengelolaan LKM. Sehingga semakin baik tingkat SDM maka pengembangan
LKM akan semakin berjalan dengan baik.

Begitupula dengan pemasaran merupakan aspek yang menjadi penting dalam pengembangan LKM, LKM harus mampu menjangkau pasar yang luas. Sehingga semakin baik dalam pemasaran maka pengembangan LKM akan dapat terwujud dengan baik.

Modal juga merupakan salah satu indikator dalam pengembangan LKM, dengan modal yang memadai akan dapat membantu pengembangan LKM dan juga meningkatkan produktivitas kinerja LKM. Dengan demikian, semakin meningkatnya modal maka pengembangan LKM akan dapat tercapai untuk memberdayakan masyarakat dalam penanggulangan kemiskinan.

Selain itu, aspek perijinan merupakan salah satu indikator pengembangan LKM. Perijinan yang mudah akan dapat membantu dalam efisiensi pengembangan LKM. Dengan demikian, diharapkan dalam perijinan akan semakin baik.

\section{DAFTAR PUSTAKA}

Anonim. (1993) Ensiklopedi Islam: 4 Nah-Sya. PT. Ichtiar Baru Van Hoeve. Jakarta.

Fisher, Ronald C. (1996) State and Local Public Finance. Second Edition. 
Irwin, A Times Mirror Higher Education Group Inc. Company.

Ghootaert, C.1998. Social Capital, Household Welfare and Poverty in Indonesia, Local Level Institutions. Working Paper. The World Bank Social Development Family Environmentally and Socially Sustainable Development Network

Ghootaert, C.1999. Social Capital, Household Walfare and Poverty in Indonesia. Local Level Institutions Working Paper No 6. World Bank.

Ismawan, B. 2005. Micro-finance, Poverty, and Social Capital : A Case Study on Impact of Economics Intervention. Paper to be Presentated at The Asian Regional Conference jointly organized by INASIA and CDF on "The Potential and Limitations of Economic Initiatives in Grassroots Development -Current Issues and Asian Experiences" from 27th - 30th November 2000 at the BRAC Centre for Development Management (BCDM). Rajendrapur.

Bangladesh.

Sharma, M. and M. Zeller. 1997. "Repayment Performance in Group-based Credit Programs in Bangladesh: An Empirical Analysis. World Development 25(10): 1731-1742.

Widyaningrum, Nurul. (2002) Model Pembiayaan BMT dan Dampaknya Bagi Pengusaha Kecil, Studi Kasus BMT Dampingan Yayasan Peramu Bogor. Yayasan Akatiga, Bandung.

Wijono, W. 2005. Pemberdayaan Lembaga Keuangan Mikro Sebagai Salah Satu Pilar Sistem Keuangan Nasional: Upaya Konkrit Memutus Mata Rantai Kemiskinan. Kajian Ekonomi dan Keuangan, Edisi Khusus November 2005. 